\title{
On-farm wintering systems - issues to consider
}

\author{
R.D. LONGHURST ${ }^{1}$, D. MILLER ${ }^{2}$, I. WILLIAMS ${ }^{3}$ and A. LAMBOURNE ${ }^{4}$ \\ ${ }^{1}$ AgResearch Ruakura, PB 3123, Hamilton \\ ${ }^{2}$ Dexcel, Hamilton \\ ${ }^{3}$ Genetic Technologies Ltd, Hamilton \\ ${ }^{4}$ Dexcel, Napier \\ bob.longhurst@agresearch.co.nz
}

\begin{abstract}
Winter is a very important period during the dairying calendar. Regions such as Southland, with susceptible soils and extended periods with soils at saturation levels will face increasing pressure to review wintering practices. On-farm options for wintering cows to protect soils and prevent pasture damage are needed. This requires a turn-around in philosophy from taking cows to pasture/crops, to bringing supplementary feeds to cows. Specialised facilities exist such as feed pads, stand-off pads, wintering barns or Herd Homes. The advantages of such systems are reduced pugging and compaction of soils, better pasture growth and stock condition. Disadvantages may include requirements to upgrade effluent management systems to cope with more concentrated waste streams. Research has shown that pasture production can be increased by withholding stock from soils during sensitive periods. Advantage should be taken of this to fully feed stock in specialised facilities. However, cow welfare and effluent management must be prioritised to maximise the wintering benefits.
\end{abstract}

Keywords: stand-off pads, bedding materials, soil pugging, Herd Homes

\section{Introduction}

Achieving target average pasture covers and herd condition scores over winter are critical factors in determining the success of the coming lactation. During wet periods in winter, it is important to prevent stock from causing pugging and compaction damage to soils. Direct run-off of nutrient-rich soil slurry can also be an issue under current winter crop grazing practices. Wintering systems are needed that protect soil structure and pasture growth. Farmers are seeking alternatives to grazing cows on susceptible soils and causing pugging damage that will affect future pasture growth. Added to this is the desire to feed stock better and reduce feed wastage. As a result, interest in constructing specialised facilities for holding stock for varying periods of time off pasture has grown. Dairying expansion into areas with heavier soils has also focused attention on winter management. The other major issue with wintering systems revolves around handling and treating the large volume of manure and effluent generated.

Case studies were conducted on 40 farms throughout the country during 2004/05. Farmers with existing specialised facilities such as feed pads, stand-off pads, wintering barns and Herd Homes were interviewed about the advantages and disadvantages of their system. During 2005, Dexcel, together with Pioneer Brand Products, held a series of field days discussing the design and management of stand-off and feed pads during the successful "Minimising muck, maximising money" national road-show. This paper documents decision points revolving around management issues for wintering stock on dairy farms.

\section{On-farm Wintering Systems}

At least four on-farm wintering systems have been used in New Zealand. These systems provide farmers with options for keeping stock off wet soils for between 2-24 $\mathrm{h} /$ day. A brief description of these systems is outlined below and the advantages and disadvantages of each are given in Table 1. Design and management guidelines are described in Dexcel (2005a) while farmer case studies with capital and operating costs are presented in Dexcel (2005b).

Feed pad: a concreted feeding platform where cows are held for short periods of time ( $\sim 2$ hours/day) and are fed supplements. Not strictly a wintering system but can be used in conjunction with other options.

Stand-off pads: a soft surface area for holding cows for extended periods (2-20 hours/day). Carbon-rich materials such as wood chips, post peeling, bark or sawdust are the preferred bedding material for cow comfort. To work efficiently it is essential that these pads have a humped and hollowed base with subsurface drains to contain and capture the effluent.

Combination feed pad and stand-off pad: the individual pads can be built side-by-side or constructed as a self-feeding silage stack on the concrete pad with adjacent soft surface loafing area. Can be used $24 \mathrm{~h}$ a day 7 days a week (24/7) if necessary.

Wintering barn: covered shelter for housing cows for extended periods, 24/7 if necessary. Many different types of construction, usually have metal roofs, but can have hard and/or soft surfaces. 
Table 1 Advantages and disadvantages with each wintering system.

\begin{tabular}{|c|c|}
\hline Advantages & Disadvantages \\
\hline $\begin{array}{l}\text { Stand-off pad } \\
\text { Comfortable bedding surface for stock } \\
\text { Can have cows on pad for prolonged periods } \\
\text { Less damage likely in paddocks }\end{array}$ & $\begin{array}{l}\text { Surface needs scraping regularly } \\
\text { Lot of stock movements } \\
\text { Solid and liquid waste streams to manage } \\
\text { Bedding material requires annual replacement } \\
\text { Need to upgrade existing effluent system } \\
\text { Bedding materials increasingly expensive } \\
\text { Still requires access to feed either on pasture or } \\
\text { at separate feeding facility }\end{array}$ \\
\hline $\begin{array}{l}\text { Combination feed and stand-off pad } \\
\text { Can have cows on pad for extended periods, } \\
24 / 7 \text { if necessary } \\
\text { Low stock movement required } \\
\text { Stock off pasture, less damage } \\
\text { Stock can feed and rest comfortably } \\
\text { Low labour cost } \\
\text { Does not require feed-out wagon }\end{array}$ & $\begin{array}{l}\text { Pad surfaces needs scraping regularly } \\
\text { Bedding materials increasingly expensive } \\
\text { Solid and liquid waste streams to manage } \\
\text { Higher annual operating cost }\end{array}$ \\
\hline $\begin{array}{l}\text { Wintering barn } \\
\text { Stock sheltered from weather } \\
\text { Stock off pasture, } 24 / 7 \text { if necessary } \\
\text { Stock can feed and rest } \\
\text { Low annual maintenance cost }\end{array}$ & $\begin{array}{l}\text { Requires regular manure cleaning } \\
\text { Large effluent storage pond required } \\
\text { Type of surface determines cow comfort } \\
\text { High initial capital cost }\end{array}$ \\
\hline $\begin{array}{l}\text { Herd Home } \\
\text { Stock sheltered from weather } \\
\text { Stock off pasture, } 24 / 7 \text { if necessary } \\
\text { Stock can feed and rest comfortably } \\
\text { Low labour effluent system } \\
\text { Low annual maintenance costs }\end{array}$ & High initial capital cost \\
\hline
\end{tabular}

Herd Homes: a combination of feeding platform, stand-off facility and animal shelter comprising a "greenhouse" type roof over slatted concrete floors with an underfloor manure bunker. Can be used $24 / 7$ if necessary.

All wintering systems have advantages and disadvantages and full economic and nutrient budgets are required to determine the optimal solution for a property. This planning is best undertaken on an individual case by case situation as the number of variables to be considered is too great to be outlined in this paper.

\section{Benefits of Wintering Systems}

The main benefits of a wintering system are to reduce pasture damage and protect soils by removing cows from wet soils. Pugging damage has been shown to cause long-term (18 months) declines in soil physical properties by increasing bulk density, and decreasing pore size and hydraulic conductivity (Singleton \& Addison 1999). The effect of soil compaction caused by a single intensive grazing during a wet day in August can depress pasture production by $20-80 \%$, depending on soil type, with effects lasting between 4-8 months (Ledgard et al. 1996).

Ward and Greenwood (2002) showed that dairy cows can consume $70 \%$ of their daily pasture intake in $2 \mathrm{~h}$ of grazing and $80 \%$ during the first $4 \mathrm{~h}$. The same study showed that "on-off" cattle grazing for 2, 4 and $12 \mathrm{~h}$ reduced pasture yields by 19,28 and $40 \%$ respectively over the following 2 months. Dry cows can generally fulfil their nutritional needs in 3-hours of grazing (Fisher et al.2003). Keeping cows off pasture completely during autumn/winter could produce $20 \%$ more pasture annually compared with conventional pasture grazings (de Klein 2001).

Protection of soils is of paramount importance for the long-term sustainability of dairying. The successful wintering formula is to keep the cows off wet soils and reduce pasture damage so that more grass can then be grown and converted into milksolids. Using feed supplements properly in conjunction with the wintering system enables better pasture management by matching feed supply and feed demand leading to increased amounts of pasture harvested (Hedley \& Kolver 2006).

\section{Nutrients and Effluent Management}

Feed supplements, particularly if imported onto the farm, can bring significant quantities of nutrients. Using the OVERSEER ${ }^{\circledR}$ nutrient budget program will calculate the nutrients in the extra feed and help determine the increased area required for an effluent block. 
Table 2 Mean nutrient concentrations from different wintering systems. Data from analysis of manure samples collected on case study farms.

\begin{tabular}{|c|c|c|c|c|}
\hline Source & $\% D M$ & $\% \mathrm{~N}$ & $\% \mathrm{P}$ & $\% \mathrm{~K}$ \\
\hline Liquid - farm dairy & $<1.0$ & 0.045 & 0.006 & 0.035 \\
\hline Liquid - storage pond ${ }^{1}$ & $<0.5$ & 0.025 & 0.003 & 0.030 \\
\hline Solids - soft surface ${ }^{2}$ & $25-30$ & 0.35 & 0.30 & 0.20 \\
\hline Solids - hard surface ${ }^{3}$ & $15-20$ & 0.45 & 0.10 & 0.30 \\
\hline Solids - covered systems ${ }^{4}$ & $20-50$ & $0.45-0.60$ & $0.05-0.10$ & $0.50-0.70$ \\
\hline $\begin{array}{l}{ }^{1} \text { Effluent typically from feed pad or } \\
2 \text { Stand-off pads } \\
3 \text { Scraped or mechanically separat } \\
{ }^{3} \text { Wintering barns and Herd Homes }\end{array}$ & & & & \\
\hline
\end{tabular}

Developing nutrient budgets accounting for imported feeds and subsequent fertiliser savings will assist in the affordability of such systems.

The traditional all-grass wintering system where cows are block grazed at high stocking rates is environmentally hazardous because it concentrates nitrate leaching (Sprosen et al. 2002). Likewise, wintering systems that concentrate livestock in one place for extended periods of time are a potential point source of nutrient loss similar to the farm dairy. Thus management of manure produced is very important to avoid environmental damage and retain nutrients.

All Regional Councils require some form of sealing or lining for stand-off areas and containment on concrete areas so that all effluent produced can be treated. A wintering system that captures effluent will act as a large catchment for rainfall so there must also be provision for handling storm water run-off.

The volume and concentration of excreta deposited on any wintering pad will be influenced by the intensity of use, quantity and type of feed provided, and volume of stormwater. Waste streams from wintering systems are more concentrated in nutrient value compared with farm dairy effluent (Table 2). Solid manures contain more nitrogen, phosphorus, and potassium than liquid wastes. Where possible, effluent from a wintering pad should be combined with the existing farm dairy effluent system, but some upgrade or modifications to the existing system are likely to be needed to cope with the increase in volume and solids content of the effluent. A common issue facing dairy farmers is whether to separate the liquid and solid fractions or to combine for treatment. For land application systems, the effluent block area will invariably require extending unless there is either some form of solid separation or if irrigation occurs from a storage pond. If solids are to be separated, (either scraped, separated or Herd Homes bunker manure), it is more appropriate to leave land application until soil conditions are suitable. Solids can be easily spread via muck spreaders and are suitable for either pasture or cropping paddocks.

\section{Animal Welfare and Bedding Materials Resting time}

There is a tension between balancing the environmental and animal welfare aspects of wintering stock. Regional Councils require concreted areas so that effluent can be more easily contained before treatment. However for the animals' welfare, cows require specific areas and prefer certain types of surfaces for lying on. Animal behaviour studies on standing-off cows in the Waikato by Fisher $e t$ al. (2003) found that, when held for $21 \mathrm{~h}$, the time spent lying on a wood chip surface $(11.9 \mathrm{~h})$ was significantly longer $(\mathrm{P}<0.001)$ than on concrete $(7.0 \mathrm{~h})$, metal raceways $(5.7 \mathrm{~h})$ or small sacrifice paddock area $(6.9 \mathrm{~h})$. Further, when returned to pasture for $3 \mathrm{~h}$ grazing, the cows on treatments where lying down was reduced, attempted to compensate for tiredness by lying down when on pasture. This would result in reduced intake during a restricted grazing period. In a similar study in Southland, lying times for cows on covered sawdust pads $(10.2 \mathrm{~h})$ was not significantly different to uncovered sawdust pads (11.5 h) (Stewart et al. 2002). Studies of cows on pasture have shown that they typically lie down for 9.6-11.8 h per day (Singh et al. 1993).

\section{Soft surface materials}

When planning a wintering system where cows would be withheld from pasture for extended periods, consideration of suitable bedding materials is important. The choice of soft surface material depends largely on physical availability and reasonable cost. Inert materials like sand do not perform well, whereas carbon-rich materials such as wood chips, post peelings, bark are reported by farmers to have worked well. Sawdust works well when used as a layer below other materials (e.g. bark), but it should not be placed directly above the drainage coil as blockages are bound to occur. The effectiveness of carbon-based pad bedding is dependent on good design and management. In particular there needs to be comprehensive subsurface drainage, appropriate stocking densities and regular maintenance. 
The top $5 \mathrm{~cm}$ surface layer of accumulated manure needs to be scraped off on a weekly or fortnightly basis to increase cow comfort and reduce the risk of mastitis infection. The solid manure scrapings should be stockpiled on an impervious surface until soil conditions allow for land application.

Stocking densities need to be 5-6 $\mathrm{m}^{2}$ per cow for periods over $12 \mathrm{~h}$ per day and increased to $9-10 \mathrm{~m}^{2}$ for longer-term $24 \mathrm{~h}$ per day/7 days per week usage (Dexcel, 2005a). Following current area recommendations of $8 \mathrm{~m}^{2}$ per cow for extended standing-off periods, requires approximately $6 \mathrm{~m}^{3} /$ cow of wood chip in the initial construction and a further $2 \mathrm{~m}^{3} /$ year for annual cleaning and replacement.

\section{On-going availability}

While carbon-based materials create a comfortable surface for resting stock there are issues concerning availability of supply and escalating costs. Competition for these materials as fuel stock for co-generation energy plants means that it is costing more for farmers to secure supplies, particularly in the North Island. Some farmers have resorted to chipping fallen trees. An average sized Pinus radiata tree (400 $\mathrm{mm}$ diameter) is likely to yield 3$4 \mathrm{~m}^{3}$ if put through a chipper. Another possibility may be to shred green wastes currently being land filled, but the suitability and cost of this has not yet been studied.

\section{ACKNOWLEDGEMENTS}

This work has been funded through Dairy InSight and the Sustainable Farming Fund.

Our thanks to the many farmers who assisted with these two projects.

\section{REFERENCES}

De Klein, C.A.M. 2001. An analysis of environmental and economic implications of nil and restricted grazing systems designed to reduce nitrate leaching from New Zealand dairy farms. II. Pasture production and cost/benefit analysis. New Zealand Journal of Agricultural Research 44: 217-235.

Dexcel. 2005a. Minimising muck, maximising money 1: Stand-off and feed pads design and management guidelines, $44 \mathrm{pp}$. Dexcel, Hamilton.

Dexcel. 2005b. Minimising muck, maximising money 2: Stand-off and feed pads case studies, $48 \mathrm{pp}$. Dexcel, Hamilton.

Fisher A.D.; Stewart M.; Verkerk G.A.; Morrow C.J.; Matthews LR. 2003. The effects of surface type on lying behaviour and stress responses of dairy cows during periodic weather-induced removal from pasture. Applied Animal Behaviour Science 81: 1-11.

Hedley, P.; Kolver, E. 2006. Achieving high performance from a range of farm systems. pp. 147166. In: Proceedings of the 4th Dairy3 Conference.

Ledgard, S.F.; Thom, E.R.; Singleton, P.L.; Thorrold, B.S.; Edmeades, D.C. 1996. Environmental impacts of dairy systems. Proceedings of Ruakura Farmers' Conference 48: 26-33.

Singh, S.S.; Ward, W.R.; Lautenbach, K.; Hughes, J.W.; Murray, R.D. 1993. Behaviour of first lactation and adult cows while housed and at pasture and its relationship with sole lesions. The Veterinary Record 133: 469-474.

Singleton, P.L.; Addison, B. 1999. Effects of cattle treading on physical properties of three soils used for dairy farming in the Waikato, North Island, New Zealand. Australian Journal Soil Research 37: 891902.

Sprosen, M.S.; Ledgard, S.F.; Lindsey, S.B.; Macdonald, K.A. 2002. Effect of stocking rate on leaching of nitrate and associated nutrients. pp 183-188 In: Dairy farm soil management. Eds L. D Currie; P. Loganathan. Occasional report No. 15. Fertiliser and Lime Research Centre, Massey University, Palmerston North.

Stewart, M.; Fisher, A.D.; Verkerk, G.A.; Mathews, L.R. 2002. Winter dairy grazing systems: management practices and cow comfort. Proceedings of the New Zealand Society of Animal Production 62: 44-48.

Ward, G.; Greenwood, K. 2002. Research and experiments in treading and wet soil management in Victoria. pp 47-59 In: Dairy farm soil management. Eds. L.D. Currie; P. Loganathan. Occasional report No. 15. Fertiliser and Lime Research Centre, Massey University, Palmerston North. 